\title{
Application of Remote Sensing and GIS in Sinuosity and River Migration Analysis of the Lower Parts of River Niger in the Niger Delta
}

\author{
Akana, S. Tombra ${ }^{12 *} \quad$ Akpofure, Edirin $^{1}$ \\ 1.Department of Geology, Niger Delta University, Wilberforce Island, Bayelsa State, Nigeria. \\ 2.Department of Geology, Pan African University Life and Earth Science Institute, University of Ibadan, Ibadan \\ Nigeria.
}

This research is financed by the African Union in collaboration with Pan African University Life and Earth Sciences (including health and Agriculture), Ibadan, Nigeria and University of Ibadan, Ibadan Nigeria.

Abstract

Sinuosity and river migration analysis of the lower parts of the River Niger in Niger Delta from Onitsha to the coast has been done using various Landsat images during 1985 to 2015 . The transect method was used for the river shifting measurement. The study area consists of a stretch characterized by uneven meandering and migration. Consequently, the adjacent areas are susceptible to flooding that causes significant losses of crops, property, livestock, and human lives. During the study period, the channel pattern moved from a sinuous-straight to straight-sinuous pattern with sinuosity reducing in the upper portions of the channel. It was found that in the upper portions of River Niger, the west bank of the channel was subjected to more erosion and that the river is migrating towards the west. In the lower portions of the River Niger, the east bank is subjected to more erosion and thus the channel is migrating towards the east. The width of the meander belt ranged from less than $1 \mathrm{~km}$ to $4.9 \mathrm{~km}$ with an average of about $2 \mathrm{~km}$. Based on the findings of this study, it is suggested that the flood protection structures are crucial for the west bank in the upper reaches and the east bank in the lower portions of the channel in the study area. It is further suggested that these structures be constructed outside the meander belt of the river.

Keywords: Sinuosity. Channel migration. Meander belt. Channel pattern. GIS. Landsat images.

DOI: $10.7176 / \mathrm{JEES} / 9-4-08$

Publication date: April $30^{\text {th }} 2019$

\section{Introduction}

Rivers are important not only as the conveyor of the products of continental denudational processes to the major sinks (oceans and lakes), but also as a natural resource for a wide range of human activities and uses especially transportation, recreation, irrigation, fishing, water and energy supply. Knowledge of the forms, energetics and dynamics of rivers, therefore, is of importance as such an understanding can assist land and natural resource managers in taking necessary measures to minimize damage (e.g., alterations of aquatic and riparian ecosystems, damage to property) conserve biodiversity (Gilvear et al. 2000) and plan for sustainable utilization. Rivers are naturally sinuous for much of their lengths, and it has been widely reported that the distance any river is straight does not exceed ten times its width at that point (Leopold and Langbein, 1966). Attempts have been made, therefore, to classify streams based on the degree to which a river departs from a straight line, its sinuosity.

Most rivers such as the River Niger, show significant change in sinuosity through time and hence their planforms reflect not only the geomorphic history but the geological controls such as active tectonics, tributary contributions and other factors affecting valley slopes (Burnett and Schumm 1983; Wyzga 2006). The study of the sinuosity index of a drainage line helps in evaluating the effect of terrain over river course and vice-versa (Panda and Bora 1992). Gillespie and Giardino (1997) evaluated the river sinuosity of Brazos river of Texas and found that the size of the river bends is influenced more by the composition of the river channels than by the peak flows. Similarly, Timar (2003) revealed that remarkable sinuosity changes have been found to correlate with discharge and sediment load changes at the interflow of tributaries. Rawat et al. (2011) studied the relationship among the sinuosity index, morphometric factors and natural hazard potential of third-order river basins of Kossi river basin in Lesser Himalayas. Harvey (2007a) identified three types of high sinuosity bedrock channels from the Almeria region of southeast Spain, and suggested that their distributions are related to gradient increase during incision in response to (1) regional tectonics, (2) local tectonic deformation, (3) tectonicallyinduced drainage ponding and breaching, (4) river capture and (5) eustatic sea level change. Even the smallest changes in the topography affect the sinuosity of low-gradient rivers (Holbrook and Schumm 1999), providing hints on on-going microtopographic changes. Nathan (2005) observed that the unusually high degree of sinuosity exhibited by the American River near its confluence with the Rubicon River is related with the coincidence of hinge zone of moderately to steeply plunging asymmetric folds with the axis of the meanders. Barbour et al. (2009) evaluated a quantitative relationship between regional climatology and sinuosity, and it has been 
postulated that the rivers, which have more relative variance in discharge, tend to have greater lateral mobility. Decrease in flood plain storage and stream power levels higher than the channelization also control the geometry of sinuosity. Constantine and Dunne (2008) suggested that the size frequency distribution of oxbow lakes within the flood plains can be predicted using channel sinuosity studies. While quantifying the geomorphology of Doodhganga stream in Kashmir Himalaya, Hussain and Pandit (2011) emphasized that the anthropogenic intervention may alter the river sinuosity. Stanistreet et al. (1993), after studying the river channels on the Okavango Fan, recorded that bed load meandering and low-sinuosity fluvial channel systems are possible where vegetation is sufficient to produce confining peat levees. Investigations carried out by Ebisemiju (1994) in the Elemi river basin, southwestern Nigeria suggested that small intermittent streams in the seasonally wet humid tropics have a tendency to develop very sinuous channels characterized by compound and highly convoluted loop. He also presented that the dominant factor controlling the degree of sinuosity is channel bank resistance to lateral erosion as influenced primarily by the nature of riparian vegetation and secondarily by the percentage silt/clay in channel bank sediment. Fashae et al. (2015) investigated downstream morphologic characteristics of the alluvial section of the lower River Ogun, Nigeria and revealed that the ratio of stream channel length to down valley distance (sinuosity) indicated the stream type and how it would respond to channel and valley slope adjustments. Tukur et al. (2003) through studies carried out in River Gongola north-eastern Nigeria, comparing it's pre-dammed and post dammed geomorphic characteristics suggests a reduction in sinuosity and increased braiding in rivers which have been dammed.

Channel dynamics represent an integral component in the evolution of vast alluvial floodplains as well as the disturbance regime vital for floodplain patterns. Alluvial rivers are inherently dynamic in nature, responding to the variation in water and sediment inputs (Yang et al. 1999). Alterations in these inputs either natural or anthropogenic result in changes in the planform/channel pattern, sinuosity, and braiding index (Knighton 1984).

Scientists have also discussed the response of alluvial channels to tectonically-induced gradient changes, especially in terms of channel pattern responses (Burnett and Schumm 1983; Schumm et al. 2000). The consensus appears to be that tectonically induced gradient steepening may lead to heightened channel activity, resulting in accelerated erosion either by incision or by lateral erosion, and an increase in sinuosity (Keller and Pinter 1996). With larger rivers and lower gradients, lateral activity might dominate leading to floodplain formation and there is a switch from a bedrock channel to an alluvial channel within a confined rock valley (Harvey 2007b).

Remote sensing is an active tool to interpret not only the structural controls (Ramasamy 2006; Youssef et al. 2009; Madani and Emam 2011), channel migration (Ramasamy et al. 1991; Gilvear et al. 2000; Yang et al. 1999) delineate water potential zones (Edet et al. 1996;) but also the tectonic controls in river sinuosity (Jain and Sinha 2004; Jain and Sinha 2005). Hassan and Klein (2002) by using aerial photographs studied the fluvial characters of Jordan River and remarkably concluded that the sinuosity of the river has been increased by $25 \%$ due to the drop in the mean sea level of Dead Sea. Allen (1964 and 1970) used aerial photographs to delineate the lateral extent of the various mega and sub sedimentary environments in the Niger Delta. The use of GIS in combination with remote sensing is widely applied in the delineation of ground water potential zones within basement complexes S-W Nigeria with most zones falling within the medium groundwater potential zone which are generally underlain by medium-porphyritic granite, biotite-hornblende granite and granite gneiss bedrock settings (Edet et al. 1996). Ebisemiju et al. (1994) investigated sinuosity in River Elemi S-W Nigeria and concluded that sinuosity of the stream channels increases with increase in channel bank resistance to lateral erosion but decreases as channel gradient increases. River sinuosity studies within Nigeria are scarce, outdated and focuses mainly on rivers within the S-W of the country. This work focuses on the use of aerial photography and Geographic information system to determine the sinuosity trend of the River Niger, in the Niger Delta basin S-S Nigeria.

\section{Study Area}

The River Niger is Africa's third longest river (4,200 km), after the Nile and the Congo (Anderson et al., 2005). It is located between the meridians of $11^{\circ} 30^{\prime}$ west and $15^{\circ}$ east, from Guinea to Chad; and between the parallels of $22^{\circ}$ north and $5^{\circ}$ north, from the Hoggar Mountains to the Gulf of Guinea. It drains a large portion of Western Africa and discharges its waters and sediment load into the Atlantic Ocean through the southern part of Nigeria which leads to the building of the complex, fragile and active Niger Delta. The Niger River encompasses six hydrographic regions, each of which is distinguished by unique topographic and drainage characteristics. The Upper Niger River Basin headwaters are in the Fouta Djallon Massif, Guinea. From there the river flows northeast, traversing the Inland Delta, a vast spreading floodplain (averaging 50,000 square kilometers) that dissipates an appreciable portion of its potential hydraulics through absorption and evaporation. When it reaches the fringes of the Sahara Desert, the Niger River turns back by forming a great bend and flowing south and east as the Middle Niger River section, then as the Lower Niger, to the Niger Delta at the Gulf of Guinea, which it reaches after being joined by its largest tributary, the Benue River (Anderson et al. 2005). The Niger Delta 
(Fig.1) is one of the largest regressive deltas in the world with an area of $300,000 \mathrm{~km}^{2}$ onshore and offshore (Kulke, 1995) and about 500,000 km3 volume of sediment deposit (Hospers, 1965). The Niger Delta is also the sixth largest oil producing delta in the world (Reijers, 1996). It is located between latitude $4^{\circ} 31^{\prime} \mathrm{N}-5^{\circ} 20^{\prime} \mathrm{N}$ and longitude $3^{\circ} \mathrm{E}-9^{\circ} \mathrm{E}$ (Asseez, 1989). The on-shore part of the delta covers about $70,000 \mathrm{~km} 2$ and is characterized by an axial distance of $221 \mathrm{~km}$ from the northern apex at Onitsha to its coastal margin apex at River Nun. River Niger joins River Benue $230 \mathrm{~km}$ before entering the Niger Delta basin at Onitsha (Allen, 1965a). The Niger bifurcates into Nun and Forcados branches about 100km from Onitsha and discharge into the eastern and the western flanks of the delta respectively (Andersen et al. 2005; Whiteman et al. 1982).

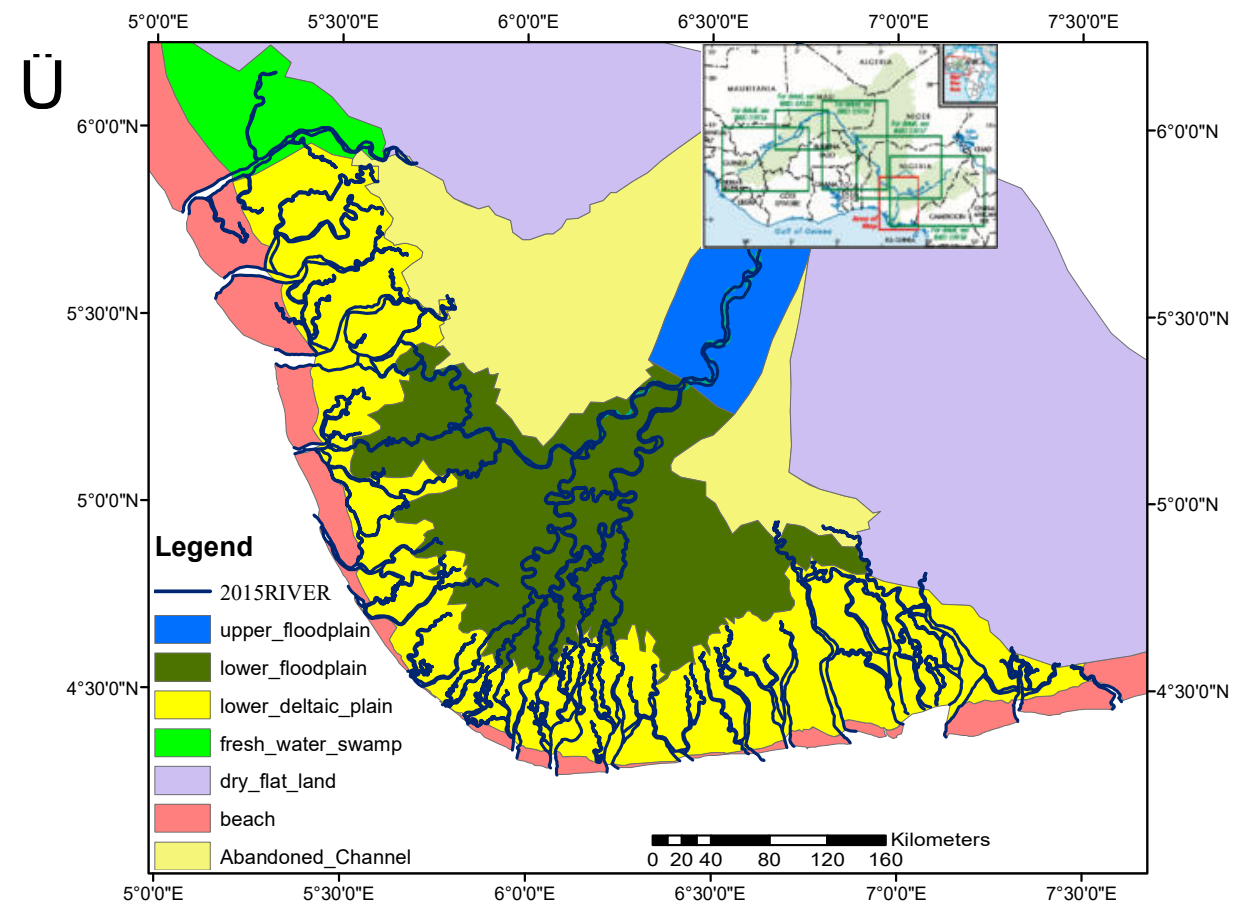

Figure 1: Geologic map of Niger Delta showing major sedimentary environments as defined by the fluvial, tidal and wave-related processes

\section{Methodology}

Satellite images of 1985, 1995, 2005, 2015 (Landsat TM-resolution $30 \mathrm{~m}$ ) were used for assessing planform changes in channel over a period. All datasets were geometrically corrected and resampled to bring to the same scale (Lillesand and Kiefer 2000). Processing and interpretation of satellite imagery to delineate various geomorphic units, channel characteristics and analysis of the dataset was achieved using ESRI ArcGIS 10.3 and ArcView 3.5 computer software using spatial analyst, data management, editor, conversion and split tools. The procedures were tailored towards extracting qualitative and quantitative parameters from the channels using geoprocessing operations. The parameters estimated from the Channel parameters include apex to toe length, reach length, reach sinuosity and channel bed.

\subsection{Computation of sinuosity parameters}

Sinuosity parameters of the River Niger and River Nun were measured using the procedure outlined by Friend and Sinha (1993). In this procedure, the stretch was divided into equal-length reaches. The mid channel and overall channel belt length was measured and then the sinuosity equation was applied. The Landsat images of the years 1985, 1995, 2005 and 2015 were used in this study (Fig. 2a-d). For sinuosity analysis, the river stretch was divided into a series of continuous reaches, each having a length of $70 \mathrm{~km}$ for River Niger. 

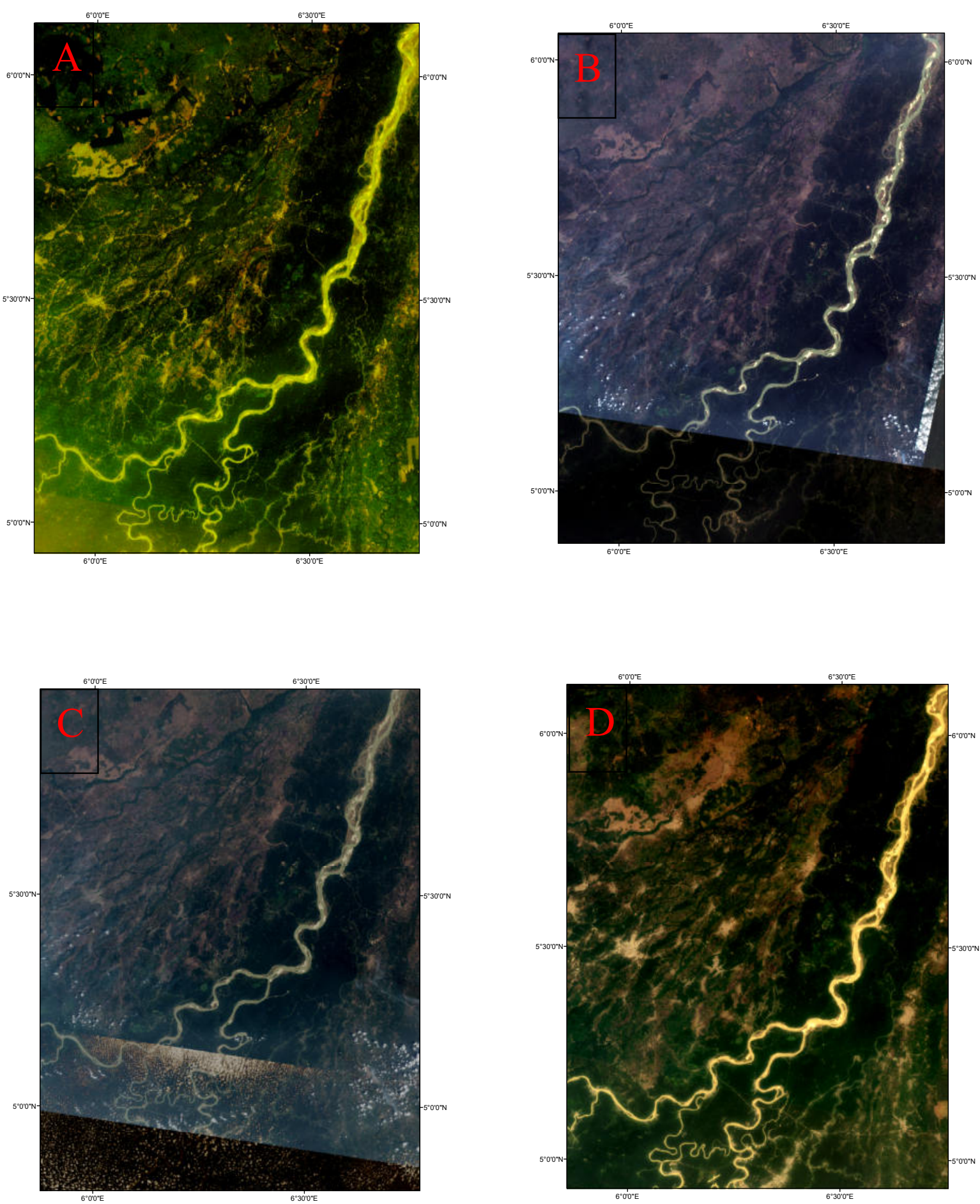

Figure 2: Floodplain and channel boundaries of the River Niger. A) 1985, B) 1995, C) 2005, D) 2015.

The overall length of the channel and the main channel length were measured using ArcGIS. The sinuosity was computed using the following equation for each reach:

$$
P=\operatorname{Imax} / I_{L R}
$$

here $\mathrm{P}$ is sinuosity, Lmax is the length of the midline of the channel (in single-channel rivers) or the widest channel (in multi-channel rivers) of the reach and LR is the overall length of the reach. 


\subsection{Computation of river shifting parameter}

There are two main methods of river migration measurements, they are; polygons method and transects method (Rapp and Abbe 2003). The transects method was used in this study and is explained below:

i. The first step: Determine the source channel (i.e the origin channel); the main channel of 1985 was considered the origin channel in this study.

ii. The second step: Divide the flood plain into transects; the floodplain of 1985 was divided into transects of $22 \mathrm{~km}$ length each.

iii. The third step: Overlay the center line of the origin channel (main channel) on all years of the flood plain transects in ArcGIS.

iv. The final step: Measure the changes in the position of the intersection of the main channel centerline with flood plain transects (migration distance) in ArcGIS for all the periods, and the direction of channel migration.

Migration rate is the outcome of dividing the migration distance by the number of years between various images used and the base image. Accordingly, the migration rates were computed and analyzed in the subsequent sections.

\section{Results and Discussion}

4.1 Analysis of sinuosity of meanders

In 1985, the River Niger averagely was a straight-sinuous channel with a sinuosity parameter less than 1.5 for most of its segments. From 1995 till the end of the study period (i.e., 2015), the sinuosity of the River Niger is observed to increase as the years progress moving it to a predominantly sinuous channel with portions of braiding in some sections (Figure 3; table 1). In 2005, the sinuosity parameters were relatively high compared to those of the other years, there seems to be a gradual increase in sinuosity from 1985 to 2005. However, in 2015, the sinuosity parameters are observed to display a minute decrease in the sections, although the average still categorizes the Niger as being sinuous as the sinuosity index value is greater than 1.5. This subtle drop in the sinuosity index 2015 may be indicative of a gradual change in the river channel from its sinuous nature to a more braided form.

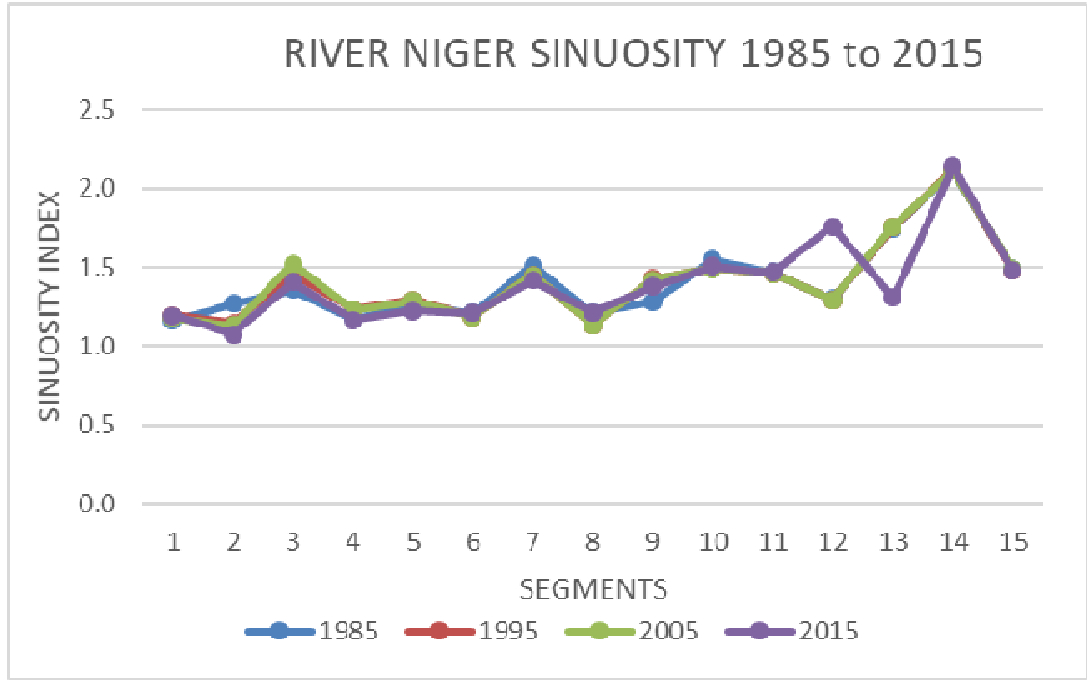

Fig. 3 Sinuosity of the River Niger $1985-2015$. 
Table 1: Sinuosity values of different segments of the river Niger from 1985 to 2015.

\begin{tabular}{|l|l|l|l|l|}
\hline SEGMENT & \multicolumn{5}{|c|}{ SINUOSITY } \\
\hline & YEAR 1985 & YEAR 1995 & YEAR 2005 & YEAR 2015 \\
\hline $\mathrm{A}$ & 1.2 & 1.2 & 1.2 & 1.2 \\
\hline $\mathrm{B}$ & 1.3 & 1.1 & 1.1 & 1.1 \\
\hline $\mathrm{C}$ & 1.4 & 1.5 & 1.5 & 1.4 \\
\hline $\mathrm{D}$ & 1.2 & 1.2 & 1.2 & 1.2 \\
\hline $\mathrm{E}$ & 1.3 & 1.3 & 1.3 & 1.2 \\
\hline $\mathrm{F}$ & 1.2 & 1.2 & 1.2 & 1.2 \\
\hline $\mathrm{G}$ & 1.5 & 1.5 & 1.5 & 1.4 \\
\hline $\mathrm{H}$ & 1.2 & 1.1 & 1.1 & 1.2 \\
\hline $\mathrm{I}$ & 1.3 & 1.4 & 1.4 & 1.4 \\
\hline $\mathrm{J}$ & 1.5 & 1.5 & 1.5 & 1.5 \\
\hline $\mathrm{K}$ & 1.5 & 1.5 & 1.5 & 1.5 \\
\hline $\mathrm{L}$ & 1.3 & 1.3 & 1.3 & 1.8 \\
\hline $\mathrm{M}$ & 1.7 & 1.8 & 1.8 & 1.3 \\
\hline $\mathrm{N}$ & 2.1 & 2.1 & 2.1 & 2.1 \\
\hline $\mathrm{O}$ & 1.5 & 1.5 & 1.5 & 1.5 \\
\hline
\end{tabular}

\subsection{Analysis of shifting behavior}

Landsat images of the years 1985, 1995, 2005, and 2015 were used in river shifting analysis. The migration distances were measured at 61 points with $5 \mathrm{~km}$ intervals and then divided to 15 segments (A-O). The source channel was overlaid with each main channel of other years. Distances between centerlines at every section were measured and migration distance for different periods were calculated. The results of the rate of river shifting, the shifting direction and the type of change occurring i.e widening (erosion) or narrowing (deposition) during all four periods are given in Table 2 and Table 3. During the first period (1985-1995), the river was shifting to the east except some parts of the lower reaches. During the second (1995-2005) and third period (2005-2015), some parts of the reaches between sections $\mathrm{G}$ and $\mathrm{H}$ and the reach between sections $\mathrm{J}$ and $\mathrm{O}$ were shifting to the west; the other reaches kept shifting in the east direction. In general, the upper sections of the River Niger are observed to be shifting to the west and the lower sections are observed to be shifting towards the east during the study period. The higher values of erosion are observed at the upper sections of the channel. These sections include sections A-F (Figure 4) and thus infrastructure located at these locations on the Delta are at high risk of destruction if conditions observed during this study remain the same.

Table 2: Rate of migration (shift) of the various segments of the Niger River during the 30year study span (Negative values indicate erosion).

\begin{tabular}{|l|r|r|r|}
\hline \multirow{2}{*}{ SEGMENT } & \multicolumn{3}{|c|}{ MIGRATION RATE (m/ YEAR) } \\
\cline { 2 - 4 } & $1985-1995$ & $1985-2005$ & $1985-2015$ \\
\hline A & -40.2 & -17.3 & -6.2 \\
\hline B & 52.0 & 25.4 & -2.1 \\
\hline D & 16.6 & 4.0 & -14.3 \\
\hline E & 100.2 & 22.4 & -4.5 \\
\hline F & -40.3 & -20.5 & -4.4 \\
\hline G & -78.3 & -42.1 & -23.4 \\
\hline H & -24.6 & -12.1 & -7.2 \\
\hline I & -37.2 & -18.9 & -3.3 \\
\hline J & -33.2 & -16.2 & -9.8 \\
\hline K & -13.5 & -8.6 & -9.3 \\
\hline L & -18.8 & -8.4 & -0.8 \\
\hline M & 78.3 & 39.6 & 25.7 \\
\hline N & 46.7 & 23.8 & 15.7 \\
\hline O & 63.1 & 34.8 & -5.0 \\
\hline
\end{tabular}

4.3 Delineation of meander belt

The channel belt refers to the zones in which the channel has been active. According to this definition, channel delineation depends on locating the areas which were occupied by the river during the previous years. As parts of 
Table 3: Type of shift and direction during all four periods within study area. (SEG- Segment; DIR- Direction of migration).

\begin{tabular}{|l|l|l|l|l|l|l|l|l|}
\hline SEG & $1985-1995$ & DIR & $1995-2005$ & DIR & $2005-2015$ & DIR & $1985-2015$ & DIR \\
\hline A & WIDENING & EAST & NARROWING & WEST & WIDENING & WEST & WIDENING & EAST \\
\hline B & WIDENING & EAST & WIDENING & WEST & WIDENING & WEST & WIDENING & WEST \\
\hline C & WIDENING & EAST & WIDENING & WEST & WIDENING & WEST & WIDENING & WEST \\
\hline D & NARROWING & EAST & WIDENING & WEST & WIDENING & EAST & WIDENING & WEST \\
\hline E & WIDENING & WEST & WIDENING & WEST & WIDENING & EAST & WIDENING & WEST \\
\hline F & WIDENING & WEST & WIDENING & WEST & WIDENING & EAST & WIDENING & WEST \\
\hline G & WIDENING & WEST & WIDENING & WEST & WIDENING & WEST & WIDENING & WEST \\
\hline H & WIDENING & WEST & NARROWING & WEST & WIDENING & WEST & NARROWING & WEST \\
\hline I & WIDENING & WEST & WIDENING & WEST & WIDENING & WEST & WIDENING & WEST \\
\hline J & WIDENING & WEST & NARROWING & WEST & WIDENING & WEST & WIDENING & EAST \\
\hline K & NARROWING & EAST & NARROWING & EAST & WIDENING & EAST & WIDENING & EAST \\
\hline L & NARROWING & EAST & NARROWING & EAST & WIDENING & WEST & WIDENING & EAST \\
\hline $\mathrm{M}$ & WIDENING & WEST & WIDENING & EAST & WIDENING & EAST & WIDENING & EAST \\
\hline N & NARROWING & EAST & NARROWING & EAST & NARROWING & WEST & NARROWING & EAST \\
\hline $\mathrm{O}$ & NARROWING & EAST & NARROWING & WEST & NARROWING & WEST & NARROWING & EAST \\
\hline
\end{tabular}

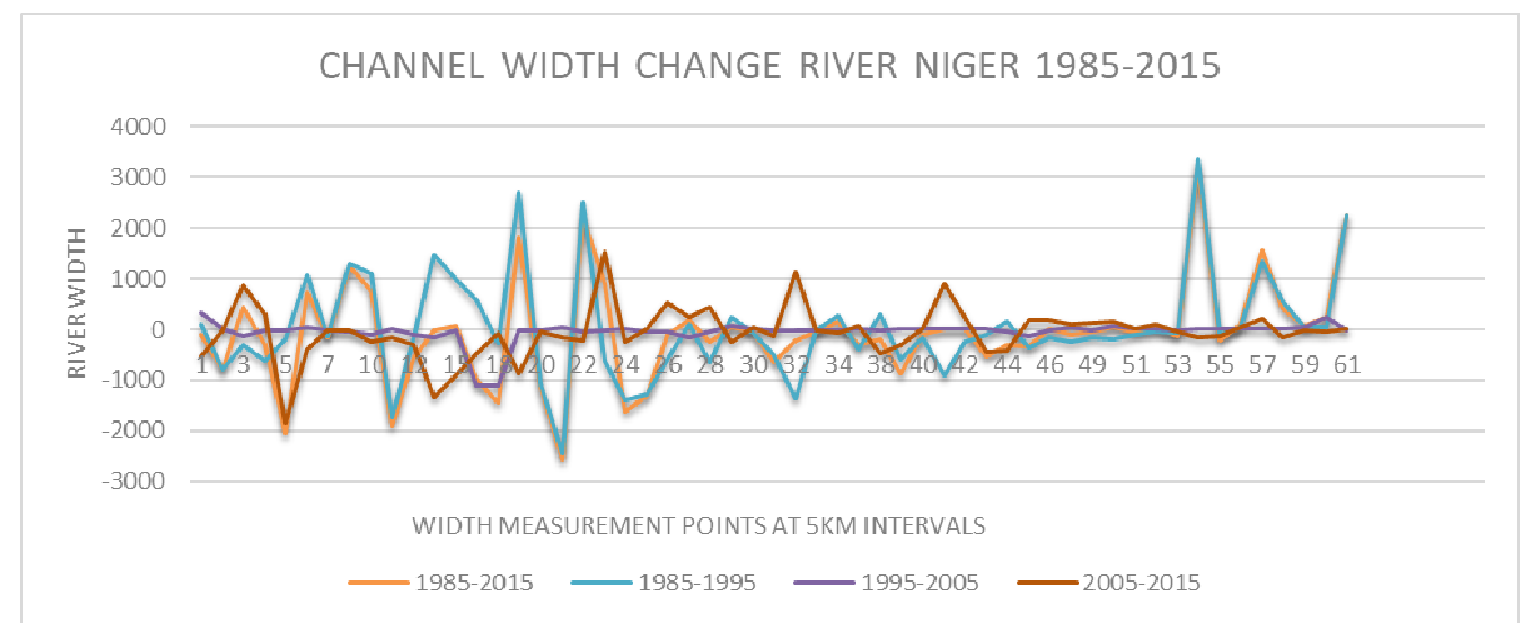

Figure 4: River Niger Migration of the four periods within the Niger Delta.

The river in the study stretch is braided, the channel belt includes both active and abounded channels. The channel belts were delineated manually by drawing simple polygons covering the channel belt in the years 1985,1995, 2005 and 2015.The polygons (channel belts) were overlaid and merged together to get the overall channel belt. Figure 5a shows the channel belt in various years and Fig.5b shows the meander belt of the River Niger in the study area. The overall belt widths were measured at all the sections, and the width varied from $0.3 \mathrm{~km}$ to about $4.9 \mathrm{~km}$ with an average value of about $2.2 \mathrm{~km}$. The delineation of the meander belt is important as it has a direct bearing on the planning of flood protection works. 


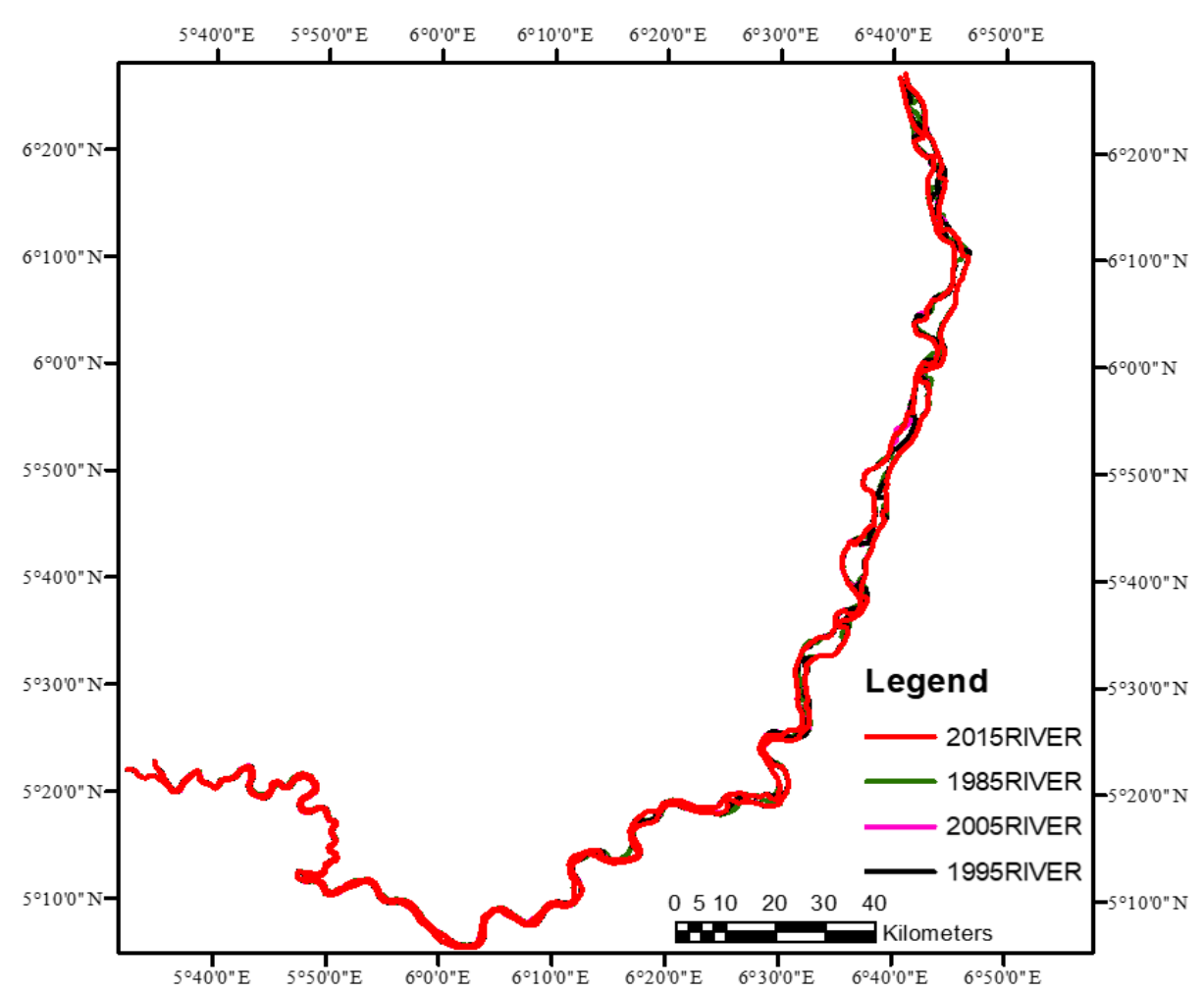

Figure 5a: Channel belts of the River Niger during the study period 1985-2015.

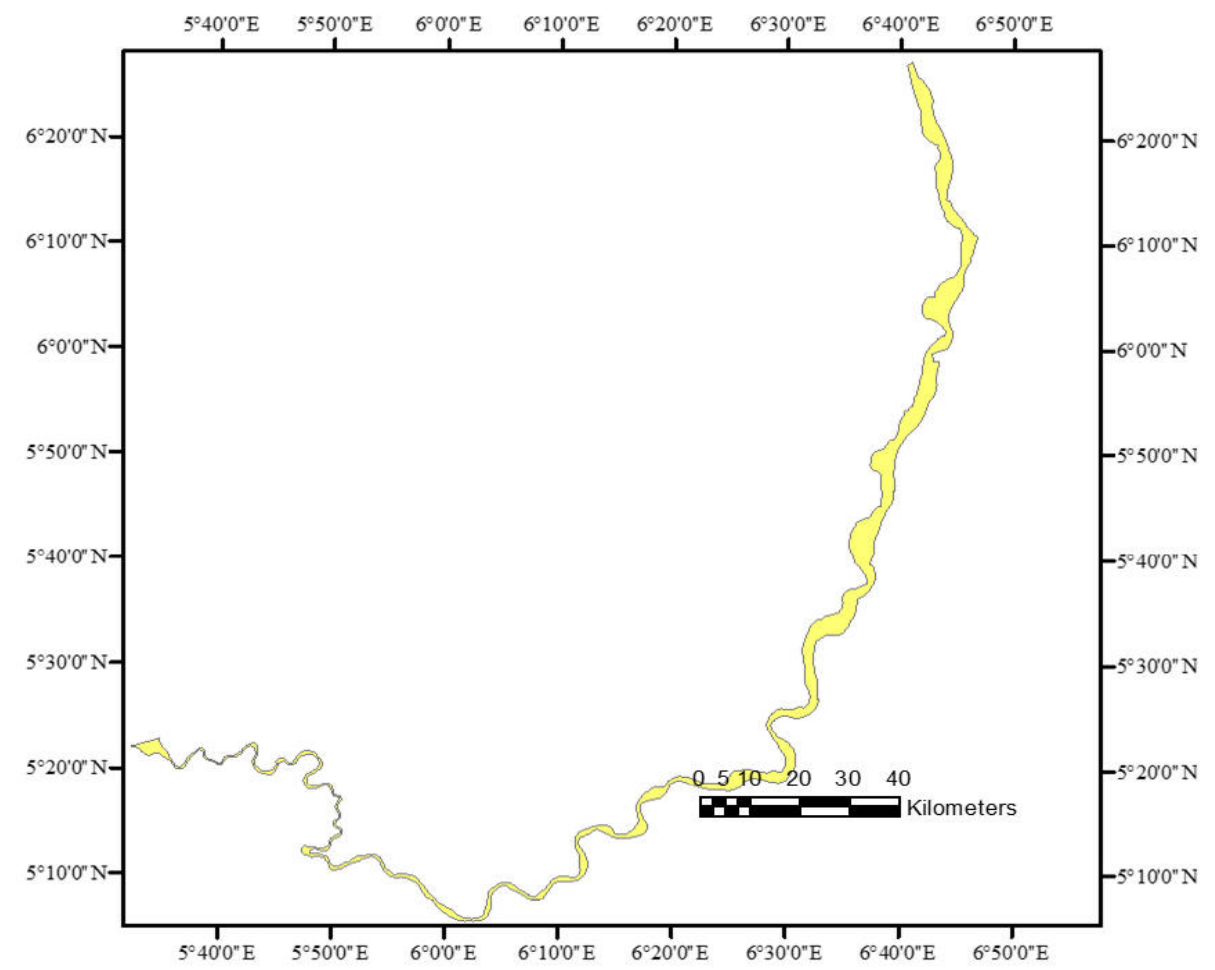

Figure 5b: Delineated meander belt of the River Niger from Onitsha to the coast.

\section{Conclusions}

The River Niger is a highly active river which has changed its channel pattern from a sinuous-straight channel at 
the beginning of the study period (1985) to a straight-sinuous channel at the end of the study period (2015); this may be due to discharge variability, urbanization and sediment load fluctuations caused by the frequent flooding occurring within the Niger Delta. In 1985, the sinuosity parameters were relatively high in segments G, J, K and M-O. The lower sections of the channel were observed to have sinuosity parameters greater than 1.5. In 1995 and 2005, the sinuosity parameter is observed to increase in segment C. The sinuosity pattern displayed in 1985 is carried through to 2005 with the lower reaches of the channel being more sinuous than the upper reaches. In 2015 sinuosity is observed to drop in most segments of the channel with sinuosity greater than 1.5 being observed in only 5 segments (J, K, L N and O) eluding to the straightening of the River Niger Channel. The River Niger migration was measured in the four periods; during the first period (1985-1995), the river generally migrated to the east except in the middle segments where it migrated westwards. In the second period (19952005) the upper reaches of the channel are observed to migrate westwards whereas the lower reaches are identified to move toward the East. The third period (2005-2015), displays a general migration to the west with a small section of the middle segments migrating towards the East. The final period which encompasses the total study period (1985-2015) the upper reaches of the channel are observed to migrate towards the west whereas, the lower reaches migrate towards the east. The west bank in the upper part of the River Niger channel is subjected to erosion and as a result, the river is shifting westward. However, this same phenomenon is affecting the east bank in the lower part of the River Niger channel. Hence mitigation processes and structures should be put in place to avoid further erosion of these banks. The channel belt width of the River Niger ranged from less than 1 $\mathrm{km}$ to about $4.9 \mathrm{~km}$ with an average of about $2 \mathrm{~km}$. Belt width of about $2 \mathrm{~km}$ is normal for an active river like the Niger that practically single handedly drains the Niger Delta. As a result of the recurrent flooding in this region over the years, the present study will help the stakeholders in better planning and protection of the environment and infrastructure in this area.

\section{REFERENCES}

Allen JRL (1964) The Nigeria continental margin bottom sediments, Sub- marine Morphology and Geological evolution. Marine Geology, vol. 1, p. 289-332.

Allen JRL (1970) Sediments of the modern Niger Delta. In Deltaic sedimentation: Modern and ancient, vol. 15, ed. J.P. Morgan, 138-151. Society of Economic Paleontologists and Mineralogists Special Publications.

Allen JRL (1965a) Late Quaternary Niger Delta and adjacent areas; sedimentary environments and lithofacies, American Association of Petroleum Geologist, Bulletin, vol. 49, p. 547-600.

Anderson JB (2005) Diachronous development of late Quaternary shelf margin deltas in the northwestern Gulf of Mexico: Implications for sequence stratigraphy and deep-water reservoir occurrence, in Giosan, L., and Bhattacharya, J.P., eds., River Deltas-Concepts, Models, and Examples: SEPM, Special Publication 83, p. 257-276

Asseez LO (1989) Review of the Stratigraphy, Sedimentology and Structure of the Niger Delta, In: Kogbe C. A. (ed), Geology of Nigeria, Lagos, Elizabethan Publishing Co. p. 311-324.

Barbour JR, Strark CP, Lin CW, Chen H, Horng MJ, Ko CP, Yi TC, Tsai TT, Chang WS, Lee SP, Huang C (2009) Magnitude frequency distributions of boundary shear along a rapidly eroding bedrock river. Geophys Res Lett. doi:10.1029/2008GL035786

Burnett AW, Schumm SA (1983) Alluvial river response to neotectonic deformation in Louisiana and Mississippi. Science 222:49-50

Burnett AW, Schumm SA (1983) Alluvial river response to neotectonic deformation in Louisiana and Mississippi. Science 222:49-50

Constantine JA, Dunne T (2008) Meander cutoff and the controls on the production of oxbow lakes. Geology 36(1):23-26

Ebisemiju FS (1994) The sinuosity of alluvial river channels in the seasonally wet tropical environment: Case study of river Elemi, southwestern Nigeria. Catena 21 (1994) 13-25

Edet AE (1996) Evaluation of borehole sites based on air photo derived parameters. Bull Int Assoc Eng Geol 54 :71-76

Fashae OA, Faniran A (2015) Downstream morphologic characteristics of the alluvial Section of lower river Ogun, Nigeria. Journal of Environmental Geography 8 (1-2), 1-10. DOI: 10.1515/jengeo-2015-0001

Friend PF, Sinha R (1993) Braiding and meandering parameters. Braided Rivers, Geological society special publication no75 , pp 105-111

Gillespie BM, Giardino JR (1997) The nature of channel planform change: Brazos River, Texas. Tex J Sci 49(2):109-142

Gilvear D, Winterbottom S, Sichingabula H (2000) Character of channel planform change and meander development: Luangwa River, Zambia. Earth Surf Proc Land 25(4):421-436

Gilvear D, Winterbottom S, Sichingabula H (2000) Character of channel planform change and meander development: Luangwa River, Zambia. Earth Surf Proc Land 25(4):421-436.

Harvey AM (2007a) High sinuosity bedrock channels: response to rapid incision-examples in SE Spain. Rev C\&G 21(34):21-47

Harvey AM (2007b) Geomorphic instability and change-introduction: implication of temporal and spatial scales. Geomorphology 84:153-158

Hassan MA, Klein M (2002) Fluvial adjustment of the lower Jordan River to a drop in the Dead Sea level. Geomorphology 45(1-2):21-33

Holbrook J, Schumm SA (1999) Geomorphic and sedimentary response of rivers to tectonic deformation: a brief review and critique of a tool for recognizing subtle epirogenic deformation in modern and ancient settings. Tectonophysics 
305:287-306

Hospers J (1965) Gravity field and structure of the Niger delta, Nigeria, West Africa: Geol. Soc. America Bull., v. 76, p. 407422

Hussain QA, Pandit AK (2011) Hydrology, geomorphology and Rosgen classification of Doodhganga stream in Kashmir Himalaya, India. Int J Water Res Environ Eng 3(3):57-65

Jain V, Sinha R (2004) Fluvial dynamics of an anabranching river system in Himalayan foreland basin, Baghmati river, north Bihar plains, India. Geomorphology 60(1-2):147-170

Jain V, Sinha R (2005) Response of active tectonics on the alluvial Baghmati River, Himalayan foreland basin, eastern India. Geomorphology 70:147-170

Keller EA, Pinter N (1996) Active tectonics: earthquakes, uplift and landscape. Prentice Hall, New Jersey, 362 pp

Knighton D (1984) Fluvial forms and processes: a new perspective. Arnold, London, $383 \mathrm{pp}$

Kulke H (1995) Nigeria, In: Kulke, H., Regional Petroleum Geology of the World. Part II: Africa, American, Australian and Antarctica: Berlin, Gebruder Borntraeger, p.143-172

Leopold LB, Langbein WB (1966) River meanders. Sci Am 214(6):60-69

Lillesand TM, Kiefer RW (2000) Remote sensing and image interpretation, 4th edn. Wiley, Singapore, 724 pp

Madani AA, Emam AA (2011) SWIRASTER band ratios for lithological mapping and mineral exploration: a case study from El Hudi area, southeastern desert, Egypt. Arab J Geosci 4(1-2):45-52

Nathan TM (2005) Relationship between fold geometry and channel sinuosity of the middle fork of the American River near Horseshoe Bar, Sierra Nevada, California. Geol Soc Am Abst Programs 37(4):74

Panda PC, Bora HN (1992) A study on sinuosity index of Siang River and its major tributaries: Arunachal Pradesh. In: Rai RK, Mahapatra AC, Goel ND (eds) Environmental management: physio-ecological facets, vol. 1. Rawat publications, New Delhi, pp 97-102

Ramasamy SM (2006) Remote sensing and active tectonics of South India. Int J Remote Sens 27(20):4397-4431

Ramasamy SM, Bakliwal PC, Verma RP (1991) Remote sensing and river migration in Western India. Int J Remote Sens 12(12):2597- 2609

Rapp CF, Abbe TB (2003) A framework for delineating channel migration zones. Ecology Publication\# 30-06-027.

Rawat PK, Tiwari PC, Pant CC (2011) Morphometric analysis of third order river basins using high resolution satellite imagery and GIS technology: special reference to natural hazard vulnerability assessment. E-Int Sci Res J 3(2):70-87

Reijer TJA (1996) Selected Chapter on Geology: Sedimentary Geology and Sequence Stratigraphy in Nigeria and three case studies as a Field Guide, Warri, SPDC Corporate Reprographics.

Reyment RA, (1954) Aspects of the geology of Nigeria: Ibadan Univ. Press.

Reyment RA, (1954) The Cretaceous Ammonoidea of southern Nigeria and the southern Cameroons: Geol. Survey Nigeria Bull., v. 25, 112 p. 1965,

Reyment RA, (1954) The stratigraphy of the southern Cameroons: Geol. Foren. Stockholm Forh., Bd. 76, h. 4, p. 661-683. 1955

Schumm SA, Dumont JF, Holbrook JM (2000) Active Tectonics and Alluvial Rivers. CUP, Cambridge, 276 pp

Stanistreet IG, Cairncross B, McCarthy TS (1993) Low sinuosity and meandering bedload rivers of the Okavango Fan: channel confinement by vegetated levees without fine sediment. Sediment Geol 85:135-156

Timar G (2003) Controls on channel sinuosity changes: a case study of the Tisza River, the Great Hungarian Plain. Quaternary Sci Rev 22(20):2199-2207

Tukur A, Mubi A. (2002). Impact of Kiri dam on the lower reaches of river Gongola, Nigeria. GeoJournal. 56. 93-96. 10.1023/A:1022449113407.

Wyzga B (2006) River response to channel regulation: case study of the Raba River, Carpathians, Poland. Earth Surf Proc Land 18(6):541-556

Yang X, Damen MCJ, Zuidam RA (1999) Satellite remote sensing and GIS for the analysis of channel migration changes in the active Yellow River Delta, China, JAG 1 vol. 1 - Issue 2

Youssef AM, Hassan AM, Mohamed AEMM (2009) Integration of remote sensing data with the field and laboratory investigation for lithological mapping of granitic phases: Kadabora pluton, Eastern Desert, Egypt. Arab J Geosci 2(1):69-82 